\title{
MITRAL VALVE REPLACEMENT WITH MECHANICAL VALVES IN CHILDREN UNDER TWO YEARS OF AGE
}

\author{
L. Daou, MD, D. Sidi, MD, P. Mauriat, MD, G. Butera, MD, J. Kachaner, MD, P. R. Vouhé, MD, and D. Bonnet, MD, \\ Paris, France
}

Repair of severe congenital mitral valve disease during the first years of life is still a therapeutic challenge. ${ }^{1}$ Mechanical valves are the most viable alternative when reconstructive procedures have failed because in this age range early calcifications and very fast deterioration are likely to occur with bioprostheses. $^{1-3}$ Most authors are reluctant to perform mitral valve replacement (MVR) in young infants because of higher morbidity and risk of anticoagulation. ${ }^{4}$ Here we report on 14 children who underwent MVR with mechanical prostheses before 2 years of age.

Patients and methods. Between December 1985 and December 1999, 14 children (median age, 5.6 months; median weight, $5.9 \mathrm{~kg}$ ) underwent MVR with mechanical prostheses for untractable congestive heart failure, elevated pulmonary artery pressure, or both. Mitral lesions and associated cardiac malformations are shown in Table I. Eleven (78\%) patients had previous procedures before MVR (Table I), with an attempted mitral valve repair in $6(43 \%)$ patients. The mitral valve was exposed through the right atrium and the interatrial septum in 9 patients and through the left atrium in the remaining 5 patients. Resection of the subvalvular mitral apparatus was performed in all patients. Table II summarizes the MVR characteristics.

Results. In-hospital mortality was 3 of 14, with 2 early deaths (preoperative brain damage and periprosthetic mitral regurgitation with death at redo operation) and 1 late death after 7 months in the intensive care unit. One patient (patient 8) required implantation of a pacemaker for postoperative atrioventricular block. One patient (patient 10) had transient left ventricular dysfunction.

No hemorrhage was observed. One patient experienced valve thrombosis 3 months after discharge and fully recovered after thrombolytic therapy. At last follow-up examination (mean follow-up was $5.7 \pm 4$ years; range, 4 months to 13 years), all patients were doing well (New York Heart Association class II, 1 patient; New York Heart Association class I, 10 patients), mean pulmonary pressure was less than 25 $\mathrm{mm} \mathrm{Hg}$, and left ventricular function was normal without any treatment but oral anticoagulation. Three patients required repeated MVR 5, 6, and 11 years, respectively (mean, $7.3 \pm 2.4$

From the Service de Cardiologie Pédiatrique, Hôpital NeckerEnfants Malades, Paris, France.

J Thorac Cardiovasc Surg 2001;121:994-6

Copyright () 2001 by The American Association for Thoracic Surgery

$0022-5223 / 2001 \$ 35.00+0 \quad \mathbf{1 2 / 5 4 / 1 1 1 6 4 3}$

doi: $10.1067 / \mathrm{mtc} .2001 .111643$ years), after the first MVR (Table II). Indication for MVR was mitral stenosis with symptoms. There was no operative mortality or morbidity in these 3 patients.

Discussion. Our study demonstrates that in young children with severe mitral lesions not amenable to repair, MVR with mechanical valves is a reasonable alternative. In early series, mortality was high, and an atrioventricular canal was considered to increase the risk of early death. In our series the postoperative mortality rate ( $<30$ days) of MVR in children younger than 2 years of age was $14 \%(\mathrm{n}=$ 2 ; ie, close to the figures of MVR in older children). ${ }^{2,3}$ However, comparison between noncontemporary series is not possible because intraoperative management and postoperative care improved dramatically. The new models of bileaflet mechanical valves, featuring a titanium ring, enable the surgeon to rotate the prosthesis after implantation. Implantation of the valve in the supra-annular position may enable us to choose a larger prosthesis and also to avoid creation of subaortic obstruction. ${ }^{5}$ Resection of all the submitral apparatus, which is usual in MVR in children and infants, has not impaired the left ventricular function. Transprosthetic mean gradient was acceptable despite the size or the position of the mitral prosthesis. This transprosthetic gradient was measured by using Doppler ultrasonography and could probably be overestimated.

Because of an infant's growth, the prosthesis can become restrictive, and repeated MVR is then required. The sizes of prostheses implanted during this reoperation $(25,21$, and 23) were not far from adult sizes. Therefore, we anticipate that the total number of reoperations for MVR that an infant operated on at a very young age will undergo is a priori no more than that of an older child undergoing primary implantation.

Oral anticoagulant therapy is feasible in infants. Rough guidelines have been proposed to adapt the treatment to age and weight ranges. Factors that may have an effect, such as the infant's weight, drug interactions, and diet, must be taken into consideration. It is our policy to give antivitamin $\mathrm{K}$ to all children receiving a prosthetic valve. There are, however, centers that prefer using aspirin and dipyridamole. Although we did not use this alternative therapy, the risk of anticoagulation appeared acceptable in our study. Indeed, only 1 patient (patient 2) had thrombosis of the mitral prosthesis 3 months after implantation. There was no mortality or reoperation related to valve thrombosis, as has been reported in other series. ${ }^{2-4}$

In conclusion, this study demonstrates that MVR with mechanical valves in young infants is a reasonable alternative when mitral valve repair cannot be carried out or has 
Table I. Demographic data at time of MVR, associated lesions, and previous procedures

\begin{tabular}{|c|c|c|c|c|c|}
\hline $\begin{array}{l}\text { Patient. } \\
\text { No }\end{array}$ & $\begin{array}{l}\text { Age } \\
(m o)\end{array}$ & $\begin{array}{l}\text { Weight } \\
(\mathrm{kg})\end{array}$ & $\begin{array}{l}\text { Type of mitral } \\
\text { valve dysfunction }\end{array}$ & Associated lesions & Previous procedures (age) \\
\hline 1 & 2 & 4 & MR & Incomplete AVC & - \\
\hline 2 & 2 & 4.6 & MR & Aortic and subaortic stenosis & Aortic valve dilation $(3 \mathrm{~d})$ \\
\hline 3 & 5 & 5.1 & MR & Complete AVC & AVC repair, MV repair (4 mo) \\
\hline 4 & 5 & 5.1 & MR & - & MV repair (3 mo) \\
\hline 5 & 5.5 & 5 & MR & Aortic stenosis & Aortic valve dilatation ( $1 \mathrm{mo})$ \\
\hline 6 & 7 & 6.7 & MS & - & - \\
\hline 7 & 8 & 5.8 & MR & Aortic stenosis & Aortic valve dilatation ( $3 \mathrm{~d}$ ) \\
\hline 8 & 9 & 5.5 & MR & VSD, subaortic stenosis & $\begin{array}{l}\text { VSD closure, subaortic stenosis resection, } \\
\text { MV repair, creation of ASD ( } 5 \text { mo })\end{array}$ \\
\hline 9 & 14 & 8 & MS & $\begin{array}{l}\text { Coarctation, bicuspid aortic } \\
\text { valve, subaortic stenosis, } \\
\text { supra-MS, PDA }\end{array}$ & Ligation of PDA (13 mo) \\
\hline 10 & 15 & 8.7 & MS & $\begin{array}{l}\text { Aortic anulus hypoplasia, } \\
\text { supra-MS, coarctation }\end{array}$ & $\begin{array}{l}\text { CoA repair }(9 \mathrm{mo}) \text {, resection of supra-MS } \\
\text { and MV repair }(11 \mathrm{mo})\end{array}$ \\
\hline 11 & 16 & 10.7 & MR & Incomplete AVC & AVC repair, MV repair (6 mo) \\
\hline 12 & 18 & 8.5 & MR & Subaortic stenosis & Resection of subaortic mitral tissue ( $2 \mathrm{mo}$ ) \\
\hline 13 & 19 & 8.6 & MS & Mild aortic stenosis & - \\
\hline 14 & 22 & 8.3 & MR & Aortic stenosis & Surgical aortic valvotomy, MV repair (1 mo) \\
\hline
\end{tabular}

$M R$, Mitral regurgitation; $A V C$, atrioventricular canal; $V S D$, ventricular septal defect; $M S$, mitral stenosis; $M V$, mitral valve; $A S D$, atrial septal defect; $P D A$, patent ductus arteriosus; $C o A$, coarctation of the aorta.

Table II. MVR procedure and follow-up

\begin{tabular}{|c|c|c|c|c|c|c|c|c|c|c|}
\hline \multirow[b]{2}{*}{ Patient } & \multicolumn{3}{|c|}{ First MVR } & \multirow[b]{2}{*}{ Concomitant procedures } & \multirow[b]{2}{*}{$\begin{array}{l}\text { Postoperative } \\
\text { death }\end{array}$} & \multicolumn{3}{|c|}{ Second MVR } & \multirow{2}{*}{$\begin{array}{l}\text { Follow-up } \\
\quad(\mathrm{mo})\end{array}$} & \multirow{2}{*}{$\begin{array}{c}\text { Mean } \\
\text { pressure } \\
\text { gradient } \\
\text { (mm } \mathrm{Hg} \text {; } \\
\text { mean, } \\
7.7 \pm 2.4 \\
\mathrm{~mm} \mathrm{Hg} \text { ) }\end{array}$} \\
\hline & $\begin{array}{c}\text { Prosthesis } \\
\text { type }\end{array}$ & $\begin{array}{l}\text { Size } \\
(\mathrm{mm})\end{array}$ & $\begin{array}{c}\text { Position } \\
(A / S A)\end{array}$ & & & $\begin{array}{c}\text { Delay } \\
(y)\end{array}$ & $\begin{array}{c}\text { Prosthesis } \\
\text { type }\end{array}$ & $\begin{array}{c}\text { Size } \\
(\mathrm{mm})\end{array}$ & & \\
\hline 1 & $\mathrm{CM}$ & 16 & $\mathrm{~A} / \mathrm{SA}$ & $\begin{array}{l}\text { Ostium primum closure and incision } \\
\text { of the coronary sinus tectum }\end{array}$ & $9 \mathrm{~d}$ & & & & & \\
\hline 2 & $\mathrm{CM}$ & 16 & SA & Ross-Manouguian procedure & & & & & 4 & 4 \\
\hline 3 & $\mathrm{CM}$ & 16 & A & - & & 5 & SJM & 25 & 86 & 6 \\
\hline 4 & $\mathrm{CM}$ & 16 & A & - & & & & & 20 & 10 \\
\hline 5 & $\mathrm{CM}$ & 18 & A & - & & 6 & SJM & 21 & 98 & 7 \\
\hline 6 & SJM & 19 & A & - & & & & & 155 & 12 \\
\hline 7 & SJM & 19 & A & - & & & & & 102 & 8 \\
\hline 8 & $\mathrm{CM}$ & 16 & SA & - & & & & & 20 & 4 \\
\hline 9 & $\mathrm{CM}$ & 16 & SA & $\begin{array}{l}\text { Subaortic stenosis resection, coarctation } \\
\text { repair, creation of ASD }\end{array}$ & & & & & 7 & 10 \\
\hline 10 & $\mathrm{CM}$ & 16 & SA & Widening of left atrium, creation of ASD & & & & & 86 & 11 \\
\hline 11 & SJM & 21 & A & - & & & & & 47 & 4 \\
\hline 12 & SJM & 21 & A & - & & 11 & $\mathrm{CM}$ & 23 & 140 & 9 \\
\hline 13 & $\mathrm{CM}$ & 16 & SA & Creation of ASD & $7 \mathrm{mo}$ & & & & & \\
\hline 14 & SJM & 23 & A & - & $5 \mathrm{~d}$ & & & & & \\
\hline
\end{tabular}

A, Annular position; SA, supra-annular position; $C M$, CarboMedics; SJM, St Jude Medical; ASD, atrial septal defect.

failed. In these rare but always complex situations for decision making, mortality was not high, and morbidity was low. Long-term anticoagulation with antivitamin $\mathrm{K}$ was feasible in infants with a low rate of severe complications. Finally, hemodynamic status and prosthesis function were excellent in all survivors at last follow-up.
Received for publication July 12, 2000; accepted for publication Sept 15, 2000

Address for reprints: Damien Bonnet, MD, Service de Cardiologie Pédiatrique, Hôpital Necker/Enfants Malades, 149, rue de Sèvres 75015 Paris, France (E-mail: damien.bonnet@nck.ap-hop-paris.fr). 


\section{REFERENCES}

1. Uva MS, Galletti L, Lacour-Gayet F, Piot D, Serraf A, Bruniaux $\mathrm{J}$, et al. Surgery for congenital mitral valve disease in the first year of life. J Thorac Cardiovasc Surg 1995;109:164-76.

2. Kadoba K, Jonas RA, Mayer JE, Castaneda AR. Mitral valve replacement in the first year of life. J Thorac Cardiovasc Surg 1990;100:762-8.

3. Zweng T, Bluett M, Mosca R, Callow L, Bove E. Mitral valve replacement in the first 5 years of life. Ann Thorac Surg $1989 ; 47: 720-4$.
4. Tait RC, Ladusans EK, El-Metaal M, Patel RG, Will AM. Ora anticoagulation in paediatric patients: dose requirements and complications. Arch Dis Child 1996;74:228-31.

5. Adatia I, Moore PM, Jonas RA, Colan SD, Lock JE, Keane JF. Clinical course and hemodynamic observations after supraannular mitral valve replacement in infants and children. J Am Coll Cardiol 1997;29:1089-94. 